\title{
Removal of Dyes from Wastewater by Adsorption onto Activated Carbon: Mini Review
}

\author{
Soonmin Ho \\ Centre for American Education, INTI International University, Putra Nilai, Negeri Sembilan, Malaysia \\ Email: soonmin.ho@newinti.edu.my
}

How to cite this paper: Ho, S.-M. (2020). Removal of Dyes from Wastewater by Adsorption onto Activated Carbon: Mini Review. Journal of Geoscience and Environment Protection, 8, 120-131.

https://doi.org/10.4236/gep.2020.85008

Received: March 6, 2020

Accepted: May 16, 2020

Published: May 19, 2020

Copyright $\odot 2020$ by author(s) and Scientific Research Publishing Inc. This work is licensed under the Creative Commons Attribution International License (CC BY 4.0).

http://creativecommons.org/licenses/by/4.0/

\begin{abstract}
Nowadays, wastewater from dyeing industries became a challenging issue in the world. Researchers have reported several techniques to treat those effluents based on their projects. Adsorption is the most common method because of cheap, simple and effective method. In this work, activated carbon was used for dye adsorption purpose. This adsorbent has high surface area and high porosity to remove dye. This review highlighted some important results of the last few years regarding the use of activated carbon in wastewater treatment. Research findings supported that adsorption process is spontaneous in nature. Adsorption data confirmed Langmuir model, indicating the chemisorption occurred.
\end{abstract}

\section{Keywords}

Activated Carbon, Wastewater Treatment, Dye, Adsorption, Surface Area

\section{Introduction}

Dye consisted of complex aromatic molecular structures, therefore very hard to degrade. Dyes have wide applications, causing the production was expected to grow from year to year. Currently, the top and second largest producer and exporter countries are China and India, respectively (Global Dyes Market Outlook, 2019). Researchers have reported that more than 100,000 commercially available dye are known annually (Menaka \& Rana, 2017). The obtained dyes are used in carpet, textile industry, food industry, paper, pharmaceutical industry, and leather industry. Wastewater produced from factories causing environmental pollutions (Konsowa, 2003), allergic dermatitis, skin irritation, and mutation in humans. Dyes could be grouped in several types such as direct dyes, reactive dyes, vat dyes, disperse dyes, azo dyes (Gregory, 1990). Reactive dye and disperse dye have accounted for top and the second largest share in dyes market (Global Dyes Market Projections, 2018). 
Currently, some techniques have been applied to remove dye from wastewater as reported by many researchers. For example, ion exchange (Tijen \& Filiz, 2019), biodegradation (Sathian et al., 2013), oxidation, membrane process, adsorption and solvent extraction (Marcelo, 2011) were discussed. Disadvantage of ion exchange is high cost, while membrane process is low flow rates. Limitation of biodegradation includes slow process and nutrition requirement. Among these techniques, adsorption method is one of the most popular techniques, because it is a rapid, inexpensive, simple, and low investment method. Activated carbon has been selected as absorbent in wastewater treatment (Ho, 2018). This absorbent has high BET surface area (Ho, 2019) and highly developed microporosity which enhanced adsorption process (Ho, 2017). Generally, several raw materials have been used for the production of activated carbon (Ho \& Munir, 2020). For example, orange peel (John et al., 2020), grape seed (Irem et al., 2014), walnut shell (Yu et al., 2019), date palm (Tanweer et al., 2012), neem leaves (Qadir \& Chhipa, 2017), rice husk (Khu \& Thuy, 2019), sugarcane bagasse (Mahanta et al., 2019), aloe vera leave (Karnan et al., 2016), watermelon rind (Jawad et al., 2019), bananas peel (Achmad et al., 2018) lemon peel (Juhaina et al., 2016), pomelo peel (Zhen et al., 2018), mango kernel (Joaquin et al., 2019) have been reported by many researchers.

The objective of this work was to prepare activated carbon by using various raw materials. Activated carbon served as the adsorbent in order to remove dyes from wastewater. Lastly, adsorption kinetic and isotherm were highlighted.

\section{Literature Survey}

\subsection{Removal of Vat Dye Using Activated Carbon}

Vat dyes were used for few thousand years ago. Basically, vat dyes are resistant to sunlight and washing. The molecular formula of Alizarin yellow (Table 1) is $\mathrm{C}_{13} \mathrm{H}_{8} \mathrm{~N}_{3} \mathrm{NaO}_{4}$. It is insoluble in water, could be used in nylon and dyeing wool. However, it irritates the eyes, skin, gastrointestinal tract, and respiratory tract. It changes from yellow (less than 5.2), red ( $\mathrm{pH} 6.8$ to 10) to blue-violet colour (more than $\mathrm{pH} 12$ ) at various $\mathrm{pH}$ values. Date palm seed was used to produce activated carbon (Nasiru \& Magaji, 2016) in the presence of phosphoric acid as activating agent. It is major biomass sources in United Arab Emirates (UAE). Carbonization was carried out in muffle furnace for 90 minutes at $400^{\circ} \mathrm{C}$. Physico-chemical characterization of obtained activated carbon such as moisture content $(15.6 \%)$, ash content $(2.9 \%)$, volatile matter $(22.2 \%)$, surface area (781 $\left.\mathrm{m}^{2} / \mathrm{g}\right)$, bulk density $(0.65 \mathrm{~g} / \mathrm{mL})$ and iodine number $(711.2 \mathrm{mg} / \mathrm{g})$ was reported.

Table 1. Examples of vat dyes.

\begin{tabular}{ccc}
\hline Molecular formula & Molecular Weight $(\mathrm{g} / \mathrm{mol})$ & Dye \\
\hline $\mathrm{C}_{13} \mathrm{H}_{9} \mathrm{~N}_{3} \mathrm{O}_{5}$ & 287.23 & Alizarin yellow \\
\hline
\end{tabular}


Adsorption study of Alizarin yellow revealed that all data fitted into Langmuir model and pseudo-second kinetic. The Langmuir isotherm was used to explain chemisorption process (Luo \& Deng, 2019). It happened when ionic bond or covalent bond (Endre, 2019) was produced between adsorbent such as activated carbon and adsorbate such as dye. Basically, adsorbate adsorption is limited to monolayer (Rackley, 2017). Production of mango seed based activated carbon through carbonization and activation process was described (Abdus \& Buhari, 2014). The seed is not the consumable part of the mango, usually discarded as waste (Babatope \& Funmilayo, 2017). The obtained activated carbon showed surface area of $819.8 \mathrm{~m}^{2} / \mathrm{g}$, percentage of yield $(62.3 \%)$, contained $52.3 \%$ carbon, and $3.38 \%$ hydrogen. Based on the experiment results, the percentage removal of Alizarin yellow dye increased as the agitation time and temperature were increased. Thermodynamic parameters highlighted that adsorption process is spontaneous (negative free energy value), endothermic (positive enthalpy value) and increased randomness (positive entropy value).

\subsection{Removal of Basic Dye Using Activated Carbon}

Basic dye is insoluble in water because of less hydrophilic group. However, soluble in water in the presence of alcohol or acetic acid. Basic dye is also called cationic dye, available in synthetic form, and can react with substances contained negatively charged. Methylene blue and crystal violet (Table 2) are examples of basic dyes. These dyes are low cost and were used in paper, veterinary and textile industries. Production of activated carbon by using coal under activating agent (zinc chloride), activation temperature $\left(500^{\circ} \mathrm{C}\right.$ ) and activation time (1 hour) (Ramazan et al., 2016). Surface area, micropore volume and total volume are $696 \mathrm{~m}^{2} / \mathrm{g}$, $0.44 \mathrm{~cm}^{3} / \mathrm{g}$ and $0.59 \mathrm{~cm}^{3} / \mathrm{g}$, respectively. Adsorption studies confirmed that all data fitted well with Langmuir isotherm. Adsorption capacity is found increased at higher temperature, indicating accelerates transportation of crystal violet to activated carbon surface. Almond shell was used to prepare activated carbon (Ahsaine et al., 2018) in the presence of $\mathrm{KOH}$ as activating agent. The loading of zirconium oxynitrate onto surface of activated carbon was reported. Researchers point out that percentage removal of dye increases at higher dosages because of binding sites and surface were promoted. Adsorption studies supported the Freundlich isotherm, indicating multilayer adsorption. Removal of methylene blue and crystal violet were observed to be 208 and $204 \mathrm{mg} / \mathrm{g}$, respectively. The date palm waste was used to prepare activated carbon (Mashael et al., 2013). Thermodynamic investigations confirmed spontaneous adsorption, exothermic process and good affinity between adsorbent and dyes. Adsorption data fitted well into Langmuir

Table 2. Examples of basic dyes.

\begin{tabular}{ccc}
\hline Molecular formula & Molecular Weight $(\mathrm{g} / \mathrm{mol})$ & Dye \\
\hline $\mathrm{C}_{16} \mathrm{H}_{18} \mathrm{ClN}_{3} \mathrm{~S} \cdot 3 \mathrm{H}_{2} \mathrm{O}$ & 373.9 & Methylene blue \\
$\mathrm{C}_{25} \mathrm{H}_{30} \mathrm{ClN}_{3}$ & 407.99 & Crystal violet \\
\hline
\end{tabular}


model if compared to Freundlich, Temkin and Elovich model. Effect of temperature onto adsorption process was studied. Researchers found that removal of crystal violet dye reduced from $94 \%$ to $89 \%$ when the temperature was increased from $25^{\circ} \mathrm{C}$ to $55^{\circ} \mathrm{C}$. Rice husk was used to synthesis activated carbon under activating agent such as sulfuric acid and zinc chloride (Kaustubha et al., 2006). Sulfuric acid treated activated carbon $(64.9 \mathrm{mg} / \mathrm{g})$ showed higher adsorption capacity if compared to zinc chloride $(61.6 \mathrm{mg} / \mathrm{g})$. The kinetic data were described by using Lagergren, and pseudo-second order model. Researchers concluded that intraparticle diffusion plays great role in the removal of crystal violet from wastewater.

The empty fruit bunch was used to prepare activated carbon by using $\mathrm{KOH}$ solution in order to enhance surface area and adsorption capacity (Egbosiuba et al., 2020). The highest surface area of $2114 \mathrm{~m}^{2} / \mathrm{g}$ was observed at $600^{\circ} \mathrm{C}, 45 \mathrm{mi}-$ nutes and 1.5 M KOH solution. Adsorption data supported Langmuir model indicating monolayer adsorption. Empty fruit bunch based activated carbon and empty fruit bunch ultra-sonicated activated carbon showed adsorption capacity of methylene blue about 400 and $435 \mathrm{mg} / \mathrm{g}$, respectively. Eucalyptus waste was employed to produce activated carbon via carbonization and activation process (Han et al., 2020). Experimental results showed that surface area (108 to 1545 $\mathrm{mg} / \mathrm{g}$ ), yield (30-9 to $54.3 \%)$, total pore volume (0.085 to $\left.1.88 \mathrm{~cm}^{3} / \mathrm{g}\right)$ and adsorption capacity (114.69 to $977 \mathrm{mg} / \mathrm{g}$ ) were strongly depended on the concentration of phosphoric acid. A well-developed pore structure was created during the impregnation process in the presence of phosphoric acid. The methylene blue adsorption process is spontaneous, exothermic, fitted well into Langmuir model and pseudo-second order kinetics. Teak wood was used to produce activated carbon under activating agent such as sulphuric acid (Gurumoorthy et al., 2019). The physico-chemical behaviors including bulk density $(0.53 \mathrm{~g} / \mathrm{cc})$, moisture content $(6 \%)$, total ash $(2.3 \%)$ and iodine number $(1012 \mathrm{mg} / \mathrm{g})$ were investigated. Adsorption data followed Langmuir model, indicating the chemisorption occurred. Removal of methylene blue was found to obey pseudo-second order kinetic.

\subsection{Removal of Acid Dye Using Activated Carbon}

Characteristics of acid dyes including anionic, were used for wool, food colorants and medical industries at acidic conditions. Several examples of acid dyes (Table 3 ) such as acid blue 83 , acid black 1 , acid orange 7 , acid blue 1 and acid yellow 36. Hazalnut bagasses were used to prepare activated carbon at $600^{\circ} \mathrm{C}$ by using zinc chloride as activating agent (Hakan et al., 2008). Absorbent has surface area of $1489 \mathrm{~m}^{2} / \mathrm{g}$. Adsorption capacities increased at lower $\mathrm{pH}$, higher concentration of dye (acid blue 350) and higher temperature. Based on the experiment results, the highest adsorption capacity about $450 \mathrm{mg} / \mathrm{g}$, at $45^{\circ} \mathrm{C}, \mathrm{pH} 2$. Adsorption data supported Langmuir model. The wood of Ailanthus altissima was used to produce activated carbon under various temperatures such as $400^{\circ} \mathrm{C}$ and $800^{\circ} \mathrm{C}$ (Bangash \& Alam, 2009). Acid blue 1 is an anionic triphenylmethane dye. 
Table 3. Examples of acid dyes.

\begin{tabular}{ccc}
\hline Molecular formula & Molecular Weight $(\mathrm{g} / \mathrm{mol})$ & Dye \\
\hline $\mathrm{C}_{45} \mathrm{H}_{44} \mathrm{~N}_{3} \mathrm{NaO}_{7} \mathrm{~S}_{2}$ & 825.97 & acid blue 83 \\
$\mathrm{C}_{22} \mathrm{H}_{14} \mathrm{~N}_{6} \mathrm{Na}_{2} \mathrm{O}_{9} \mathrm{~S}_{2}$ & 616.49 & acid black 1 \\
$\mathrm{C}_{16} \mathrm{H}_{11} \mathrm{~N}_{2} \mathrm{NaO}_{4} \mathrm{~S}$ & 350.33 & acid orange 7 \\
$\mathrm{C}_{27} \mathrm{H}_{31} \mathrm{~N}_{2} \mathrm{NaO}_{6} \mathrm{~S}_{2}$ & 566.67 & acid blue 1 \\
$\mathrm{C}_{18} \mathrm{H}_{16} \mathrm{~N}_{3} \mathrm{NaO}_{3} \mathrm{~S}$ & 377.39 & acid yellow 36 \\
\hline
\end{tabular}

Molecular weight of this dye is 566.68. Experiment revealed that it has maximum wavelength absorption about $635 \mathrm{~nm}$. Adsorption data confirmed the first order and Bangham model. Free energy, entropy and enthalpy decreased, when the temperature was increased. At higher temperature $\left(800^{\circ} \mathrm{C}\right)$, the carboxyl group disappeared to improve adsorption capacity. The car scrap tire was used to produce activation under $\mathrm{KOH}$ solution (Edris et al., 2012). Surface area and total pore volume were reported as $185 \mathrm{~m}^{2} / \mathrm{g}$ and $0.58 \mathrm{~cm}^{3} / \mathrm{g}$, respectively. Adsorption data matched well with Langmuir model if compared to Freundlich and Temkin model. Maximum removal of Acid Black 1 dye and Langmuir constant were $14.5 \mathrm{mg} / \mathrm{g}$ and $0.044 \mathrm{mg} / \mathrm{L}$, respectively. Kenya tea residue was utilized to synthesis activated carbon by using phosphoric acid under various carbonization temperatures (Behnaz et al., 2017). The obtained carbon has surface area about $832 \mathrm{~m}^{2} / \mathrm{g}$. The highest percentage removal of acid orange 7 about $98.4 \%$ at $\mathrm{pH} 2$, and dosage of $10 \mathrm{~g} / \mathrm{L}$. Adsorption data supported Freundlich model with correlation coefficient (R) of 0.97 if compared to Langmuir model $(R=0.855)$. Rice husk and sawdust were used to produce activated carbon (Malik, 2003). Adsorption capacities of acid yellow 36 dyes were $183.8 \mathrm{mg} / \mathrm{g}$ and $86.9 \mathrm{mg} / \mathrm{g}$ in sawdust and rice husk based activated carbon, respectively. Kinetic data supported pseudo first order model. Researcher found that acidic $\mathrm{pH}(\mathrm{pH} 3)$ is favorable intra particle diffusion of dye during the experiment. Jatropha husk was used to prepare activated carbon through carbonization and activation process (zinc chloride as activating agent) (Kumaravel et al., 2017). Adsorption kinetic data matched well pseudo-second order model and Freundlich isotherm. Experiment findings confirmed that lower $\mathrm{pH}(\mathrm{pH} 2)$ and higher temperature are favorable conditions for the removal of acid blue 83 dye.

\subsection{Removal of Direct Dye Using Activated Carbon}

Direct dye has some properties such as cheap, available in all colours, easily applied, water soluble. It also has an affinity to cellulosic fiber, and low photosensitivity. Hazelnut was used to prepare activated carbon by using zinc chloride as activating agent (Yavuz \& Aydin, 2006). Direct yellow 50, direct red 80 (Table 4) and direct blue 71 exhibited maximum absorbance value in 398, 527 and 587 $\mathrm{nm}$, respectively. The removal of these dyes were observed to be $11 \mathrm{mg} / \mathrm{g}$ (direct yellow 50), $14 \mathrm{mg} / \mathrm{g}$ (direct red 80) and $26 \mathrm{mg} / \mathrm{g}$ (direct blue 71), respectively. 
Table 4. Examples of direct dyes.

\begin{tabular}{ccc}
\hline Molecular Formula & Molecular Weight $(\mathrm{g} / \mathrm{mol})$ & Dye \\
\hline $\mathrm{C}_{45} \mathrm{H}_{26} \mathrm{~N}_{10} \mathrm{Na}_{6} \mathrm{O}_{21} \mathrm{~S}_{6}$ & 1373.08 & direct red 80 \\
$\mathrm{C}_{40} \mathrm{H}_{23} \mathrm{~N}_{7} \mathrm{Na}_{4} \mathrm{O}_{13} \mathrm{~S}_{4}$ & 1029.87 & direct blue 71 \\
$\mathrm{C}_{35} \mathrm{H}_{24} \mathrm{~N}_{6} \mathrm{Na}_{4} \mathrm{O}_{13} \mathrm{~S}_{4}$ & 956.82 & Direct yellow 50 \\
$\mathrm{C}_{32} \mathrm{H}_{14} \mathrm{CuN}_{8} \mathrm{Na}_{2} \mathrm{O}_{6} \mathrm{~S}_{2}$ & 780.16 & direct blue 86 \\
$\mathrm{C}_{29} \mathrm{H}_{19} \mathrm{~N}_{5} \mathrm{Na}_{2} \mathrm{O}_{8} \mathrm{~S}_{2}$ & 675.6 & Direct red 81 \\
$\mathrm{C}_{30} \mathrm{H}_{16} \mathrm{Cl}_{2} \mathrm{~N}_{4} \mathrm{Na}_{2} \mathrm{O}_{8} \mathrm{~S}_{2}$ & 741.49 & direct blue 106 \\
\hline
\end{tabular}

Orange peel was used as raw material to produce activated carbon (Ahmed at al., 2009). The maximum removal of dye (92\%) was observed in $\mathrm{pH} 2,6 \mathrm{~g} / \mathrm{L}$ (adsorbent), $100 \mathrm{mg} / \mathrm{L}$ (dye concentration). Adsorption of direct blue 86 supported Langmuir model and pseudo-second kinetic. Bamboo sawdust was utilized to synthesis activated carbon (Sarita et al., 2012). The percentage of removal of direct red 81 dye about $89 \%$. Adsorption data matched well with Freundlich and Halsey model. Kinetic data fitted into pseudo-second order. Adsorption process is endothermic, spontaneous and controlled by intra particle diffusion. Pomegranate peel was used to produce activated carbon (Amin, 2009). Adsorption process is exothermic and spontaneous in nature. The adsorption of direct blue 106 dye increased, when the adsorbent increased, low temperature and reduce in initial dye concentration. The adsorption findings confirmed pseudo-second order and intra particle diffusion. Palm ash was used to prepare low cost activated carbon (Ahmad et al., 2007). Adsorption of blue 71 dye confirmed the Freundlich model in the range of $50-600 \mathrm{mg} / \mathrm{L}$. The kinetic data fitted well with pseudo-second order model. Almond shell has been employed to prepare activated carbon (Ardejani et al., 2008). The percentage of removal of direct red 80 dye about $97 \%$ after 1 hour. Adsorption process supported pseudo-second order kinetic and Langmuir model. Orange peel was used to synthesis activated carbon (Azza et al., 2009). Adsorption data revealed that removal of direct navy blue 106 dye is physical process, fitted well to Freundlich model. This work confirmed pseudo-second order kinetic with intraparticle diffusion process.

\subsection{Removal of Reactive Dye Using Activated Carbon}

Reactive dyes were used in cotton, viscose, dyeing protein and cellulose because of cheap, brightness, simple application and have wide color range. They can produce covalent bond between the fibre polymer and reactive group. Bagasse pith was used to produce activated carbon in the presence of activating agent such as phosphoric acid and zinc chloride (Nevine, 2008) under physical and chemical activation. Removal of reactive orange dye fitted well with pseudo-second-order kinetic and intraparticle diffusion process. Jatropha curcas was employed to synthesis activated carbon (Palanivel et al., 2012). About 95\% removal for Remazol Brilliant Blue R (Table 5) was observed at the specific conditions such as $0.2 \mathrm{~g}$ 
Table 5. Examples of reactive dyes.

\begin{tabular}{ccc}
\hline Formula & Molecular weight $(\mathrm{g} / \mathrm{mol})$ & Dye \\
\hline $\mathrm{C}_{22} \mathrm{H}_{16} \mathrm{~N}_{2} \mathrm{Na}_{2} \mathrm{O}_{11} \mathrm{~S}_{3}$ & 626.54 & Remazol Brilliant Blue $\mathrm{R}$ \\
$\mathrm{C}_{27} \mathrm{H}_{18} \mathrm{ClN}_{7} \mathrm{Na}_{4} \mathrm{O}_{16} \mathrm{~S}_{5}$ & 984.21 & reactive red 194 \\
\hline
\end{tabular}

of adsorbent, and $50 \mathrm{mg} / \mathrm{L}$ of dye. The maximum adsorption of dye was observed at $\mathrm{pH} 3$, indicating strong interaction between dye and the activated carbon under this condition. Adsorption data showed that fitted well with Langmuir model, pseudo-first-order kinetic and intraparticle diffusion process. Industrial laundry sewage sludge was utilized to produce activated carbon (Tais et al., 2016). Experimental results indicated that surface area (159 to $65 \mathrm{~m}^{2} / \mathrm{g}$ ) of mesoporous activated carbon reduced when activation temperature was increased from $750^{\circ} \mathrm{C}$ to $850^{\circ} \mathrm{C}$. Adsorption kinetic supported Freundlich model and pseudo-second order. Thermodynamic parameters highlighted endothermic reaction is favored at higher temperature. Adsorption capacity of Remazol Brilliant Blue $\mathrm{R}$ about 33.5 $\mathrm{mg} / \mathrm{g}$ at activation temperature of $750^{\circ} \mathrm{C}$. The Brazilian pine fruit shell was used to produce activated carbon (Eder et al., 2008) via chemical treatment in order to enhance surface area and average porous volume. Removal of hydrolyzed reactive red 194 supported Sips isotherm and Redlich-Peterson isotherm for carbon treated with chromium, followed by acid, and chromium without acid, respectively. Researchers point out that the best conditions to reach the equilibrium in $\mathrm{pH} 2,24$ hours and at $25^{\circ} \mathrm{C}$.

\subsection{Removal of Disperse Dye Using Activated Carbon}

Properties of disperse dye such as water insoluble, free of ionizing group, the smallest dye if compared to other groups. It is synthetic dye, used for dyeing of polyester and and textile materials. Azo and anthraquinones could be found in disperse dye. Cherry stone was used to produce activated carbon via micro wave assisted phosphoric acid treatment process (Taner \& Fatma, 2016). The obtained activated carbon has higher surface area $\left(1998 \mathrm{~m}^{2} / \mathrm{g}\right)$ and micropore volume (0.937 $\mathrm{cm}^{3} / \mathrm{g}$ ). Removal of disperse yellow 211 (Table 6) favored in $\mathrm{pH} 11$, and kinetic data supported pseudo-second order model. Sawdust has been used to produce activated carbon (Rai et al., 2007). The best $\mathrm{pH}$ value about pH 2-3 for the removal of disperse blue 56 dye. The experimental data matched well with pseudo-first-order model. Euphorbia rigida was used to prepare activated carbon (Gercel et al., 2008) via chemical activation (sulphuric acid). The removal of disperse orange 25 about $118.9 \mathrm{mg} / \mathrm{g}$ at $20^{\circ} \mathrm{C}$ and confirmed the Langmuir isotherm. Kinetic data supported pseudo-second-order kinetic. Bamboo was utilized to synthesis activated carbon (Wang, 2013) in the present of phosphoric acid as activating agent. Analysis of data indicating that the highest percentage of removal of disperse red 167 was $90.2 \%$ at 15.4 hours, $50^{\circ} \mathrm{C}$, dye concentration of $50 \mathrm{mg} / \mathrm{L}$ and $12 \mathrm{~g}$ of activated carbon. Adsorption data supported pseudo-first-order kinetic and Freundlich model. Thermodynamic studies revealed that adsorption is spontaneous, endothermic process. 
Table 6. Examples of disperse dyes.

\begin{tabular}{ccc}
\hline Molecular formula & Molecular weight $(\mathrm{g} / \mathrm{mol})$ & Name \\
\hline $\mathrm{C}_{15} \mathrm{H}_{13} \mathrm{BrN}_{2} \mathrm{O}_{4}$ & 365.18 & disperse blue 56 \\
$\mathrm{C}_{24} \mathrm{H}_{26} \mathrm{IN}_{5} \mathrm{O}_{7}$ & 519.93 & disperse red 167 \\
$\mathrm{C}_{15} \mathrm{H}_{12} \mathrm{ClN}_{5} \mathrm{O}_{4}$ & 361.73 & disperse yellow 211 \\
$\mathrm{C}_{17} \mathrm{H}_{17} \mathrm{~N}_{5} \mathrm{O}_{2}$ & 323.35 & disperse orange 25 \\
\hline
\end{tabular}

\section{Conclusion}

Activated carbon has been prepared by using different raw materials. Experimental results showed that activated carbon could be used as adsorbent to remove dye from wastewater on a laboratory scale. Various types of dyes such as vat dye, basic dye, acid dye, direct dye, reactive dye and disperse dye were successfully removed from effluents. The percentage removal of dye depended on experimental conditions. In future, more and more researchers focus on the design and operational experiences with pilot plant testing of activated carbon adsorption system.

\section{Acknowledgements}

The author gratefully acknowledges the financial support provided by the INTI International University.

\section{Conflicts of Interest}

The author declares no conflicts of interest regarding the publication of this paper.

\section{References}

Abdus, N., \& Buhari, M. (2014). Adsorption of Alizarin and Fluorescein Dyes on Adsorbent Prepared from Mango Seed. Pacific Journal of Science and Technology, 15, 232-244.

Achmad, C., Widi, A., Dhoni, H., Aulia, S., \& Sari, P. (2018). Preparation of Activated Carbon from Banana Peel Waste for Reducing Air Pollutant from Motorcycle Muffler. In MATEC Web of Conferences (p. 154). https://doi.org/10.1051/matecconf/201815401021

Ahmad, A. A., Aziz, N., \& Hameed, B. (2007). Adsorption of Direct Dye on Palm Ash: Kinetic and Equilibrium Modeling. Journal of Hazardous Materials, 141, 70-76. https://doi.org/10.1016/j.jhazmat.2006.06.094

Ahmed, E., Ola, A., Amany, E., \& Azza, K. (2009). Removal of Direct Blue 86 from Aqueous Solution by New Activated Carbon Developed from Orange Peel. Journal of Hazardous Materials, 161, 102-110. https://doi.org/10.1016/j.jhazmat.2008.03.060

Ahsaine, H. A., Anfar, Z., Zbair, M., Ezahri, M., \& Alem, N. (2018). Adsorptive Removal of Methylene Blue and Crystal Violet onto Micro Mesoporous $\mathrm{Zr}_{3} \mathrm{O} /$ Activated Carbon Composite: A Joint Experimental and Statistical Modelling Considerations. Journal of Chemistry, 2018, Article ID: 6982014. https://doi.org/10.1155/2018/6982014

Amin, N. K. (2009). Removal of Direct Blue-106 Dye from Aqueous Solution Using New Activated Carbons Develop from Pomegranate Peel: Adsorption Equilibrium and Kinetics. Journal of Hazardous Materials, 165, 52-62.

https://doi.org/10.1016/j.jhazmat.2008.09.067 
Ardejani, F., Badii, K., Limaee, N., Shafaei, S., \& Mirhabibi, A. (2008). Adsorption of Direct Red 80 Dye from Aqueous Solution onto Almond Shells: Effect of pH, Initial Concentration and Shell Type. Journal of Hazardous Materials, 151, 730-737. https://doi.org/10.1016/j.jhazmat.2007.06.048

Azza, K., Ahmed, E., Amany, E., \& Ola, A. (2009). Removal of Direct N Blue 106 from Artificial Textile Dye Effluent Using Activated Carbon from Orange Peel: Adsorption Isotherm and Kinetic Studies. Journal of Hazardous Materials, 165, 100-110. https://doi.org/10.1016/j.jhazmat.2008.09.122

Babatope, A. O., \& Funmilayo, O. (2017). Comparative Adsorption of Crude Oil Using Mango (Mangifera indica) Shell and Mango Shell Activated Carbon. Environmental Engineering Research, 22, 384-392. https://doi.org/10.4491/eer.2017.011

Bangash, F. K., \& Alam, S. (2009). Adsorption of Acid Blue 1 on Activated Carbon Produced from the Wood of Ailanthus altissima. Brazilian Journal of Chemical Engineering, 26, 275-285. https://doi.org/10.1590/S0104-66322009000200005

Behnaz, N., Fahimeh, Z., Reza, M., Mahdi, S., \& Hamed, B. (2017). Removal of Acid Orange 7 Dye from Aqueous Solutions by Adsorption onto Kenya Tea Pulps; Granulated Shape. Electron Physician, 9, 4312-4321. https://doi.org/10.19082/4312

Eder, C., Betina, R., Julio, C., Nathalia, M., Bruna, M., \& Flavio, A. (2008). Application of Brazilian Pine Fruit Shell as a Biosorbent to Removal of Reactive Red 194 Textile Dye from Aqueous Solution: Kinetics and Equilibrium Study. Journal of Hazardous Materials, 155, 536-550. https://doi.org/10.1016/j.jhazmat.2007.11.101

Edris, H., Ali, R., Asgari, G., Gordon, M., \& Reza, D. (2012). Adsorption of Acid Black 1 by Using Activated Carbon Prepared from Scrap Tires: Kinetic and Equilibrium Studies. Journal of Scientific \& Industrial Research, 71, 682-689.

Egbosiuba, T. C., Abdulkareem, A., Kovo, A., Afolabi, E., Tijani, J., Auta, M., \& Roos, W. (2020). Ultrasonic Enhanced Adsorption of Methylene Blue onto the Optimized Surface Area of Activated Carbon: Adsorption Isotherm, Kinetics and Thermodynamics. Chemical Engineering Research and Design, 153, 315-336. https://doi.org/10.1016/j.cherd.2019.10.016

Endre, N. (2019). Basic Equations of Mass Transport through a Membrane Layer (2nd ed.). London: Elsevier.

Gercel, O., Gercel, H., Koparal, A., \& Ogutveren, U. (2008). Removal of Disperse Dye from Aqueous Solution by Novel Adsorbent Prepared from Biomass Plant Material. Journal of Hazardous Materials, 160, 668-674. https://doi.org/10.1016/j.jhazmat.2008.03.039

Global Dyes Market Outlook (2019).

https://www.prnewswire.com/news-releases/global-dyes-market-outlook-2018-2022-ro bust-growth-in-end-users-industries-such-as-textiles-construction-automotives-printi ng-inks-paper-and-personal-care-300796039.html

Global Dyes Market Projections (2018). http://industryresearchcompany.blogspot.com/2018/09/global-dyes-market-projection s-to-2022.html

Gregory, P. (1990). Classification of Dyes by Chemical Structure. In D. R. Waring, \& G. Hallas (Eds.), The Chemistry and Application of Dyes: Topics in Applied Chemistry (pp. 17-47). Boston, MA: Springer. https://doi.org/10.1007/978-1-4684-7715-3_2

Gurumoorthy, V., Balasubramanian, R., \& Mohan, S. C. (2019). Isotherm and Kinetic Studies of Methylene Blue Adsorption Using Activated Carbon Prepared from Teak Wood Waste Biomass. Journal of Applied Sciences, 19, 827-836.

https://doi.org/10.3923/jas.2019.827.836 
Hakan, D., Demiral, I., Fatma, T., \& Belgin, K. (2008). Adsorption of Textile Dye onto Activated Carbon Prepared from Industrial Waste by $\mathrm{ZnCl}_{2}$ Activation. Journal of International Environmental Application \& Science, 3, 381-389.

Han, Q., Jing, W., Bernard, A., Xie, J., \& Liu, Z. (2020). High Adsorption of Methylene Blue by Activated Carbon Prepared from Phosphoric Acid Treated Eucalyptus Residue. Powder Technology, 366, 239-248. https://doi.org/10.1016/j.powtec.2020.02.013

Ho, S. M. (2017). Agricultural Waste Materials for Activated Carbon Preparation: Review. In S. M. Ho, M. Abbas, K. Ramesh, A. A. Hamidi, \& C. C. Tay (Eds.), Activated Carbon Prepared from Various Precursors (pp. 1-15). Indore: Ideal International E-Publication Pvt. Ltd.

Ho, S. M. (2018). Removal of Dye by Adsorption onto Activated Carbons: Review. Eurasian Journal of Analytical Chemistry, 13, 332-338.

Ho, S. M. (2019). Study Activated Carbon Prepared from Various Fruit Peels. In G. Thomas (Ed.), Theory Applications of Chemistry (pp. 1-6). London: Book Publisher International.

Ho, S. M., \& Munir, H. K. (2020). Short Review on the Use of Oil Palm Shell in Concrete and Activated Carbon. World Journal of Nano Science and Engineering, 10, 1-13. https://doi.org/10.4236/wjnse.2020.101001

Irem, O., Selhan, K., Tay, T., \& Erdem, M. (2014). Activated Carbons from Grape Seeds by Chemical Activation with Potassium Carbonate and Potassium Hydroxide. Applied Surface Science, 293, 138-142. https://doi.org/10.1016/j.apsusc.2013.12.117

Jawad, A. H., Razuan, R., Jimmy, N., \& Lee, D. (2019). Adsorption and Mechanism Study for Methylene Blue Dye Removal with Carbonized Watermelon (Citrullus lanatus) Rind Prepared via One Step Liquid Phase $\mathrm{H}_{2} \mathrm{SO}_{4}$ Activation. Surfaces and Interfaces, 16, 76-84. https://doi.org/10.1016/j.surfin.2019.04.012

Joaquin, V., Ivan, J., Jaylym, A., Karizza, M., Erison, R., \& April, J. (2019). Production of Activated Carbon from Corn Cobs and Mango Kernels via $\mathrm{H}_{3} \mathrm{PO}_{4}$ Activation and Mediated Hydrothermal Treatment. In MATEC Web of Conferences (p. 268). https://doi.org/10.1051/matecconf/201926806020

John, K., Lin, S., Amit, K., Zhao, Y., Choi, J., Song, M., Cho, C., \& Yun, Y. (2020). Evaluation of Orange Peel Derived Activated Carbons for Treatment of Dye Contaminated Wastewater Tailings. Environmental Science and Pollution Research, 27, 1053-1068. https://doi.org/10.1007/s11356-019-07031-8

Juhaina, J., Rasu, E., \& Dinesh, K. (2016). Synthesis of Activated Carbon Using Orange and Lemon Peel for Waste Water Treatment Application. International Journal of Modern Science and Technology, 1, 178-182.

Karnan, M., Subramani, K., Sudhan, N., Sathish, M., \& Ilayaraja, N. (2016). Aloe Vera Derived Activated High Surface Area Carbon for Flexible and High Energy Supercapacitors. ACS Applied Materials \& Interfaces, 8, 35191-35202.

https://doi.org/10.1021/acsami.6b10704

Kaustubha, M., Naidu, J., Meikap, B., \& Biswas, M. (2006). Removal of Crystal Violet from Wastewater by Activated Carbons Prepared from Rice Husk. Industrial \& Engineering Chemistry Research, 45, 5165-5171. https://doi.org/10.1021/ie060257r

Khu, L. V., \& Thuy, L. (2019). Preparation of Pore Size Controllable Activated Carbon from Rice Husk Using Dual Activating Agent and Its Application in Super Capacitor. Journal of Chemistry, 2019, Article ID: 4329609. https://doi.org/10.1155/2019/4329609

Konsowa, A. H. (2003). Decolorization of Wastewater Containing Direct Dye by Ozonation in a Batch Bubble Column Reactor. Desalination, 158, 233-240.

https://doi.org/10.1016/S0011-9164(03)00458-2 
Kumaravel, K., Chinnaya, N., \& Arul, P. (2017). Kinetics and Isotherm Studies on Acid Dye Adsorption Using Thermal and Chemical Activated Jatropha Husk Carbons. Environmental Progress \& Sustainable Energy, 37, 719-732.

https://doi.org/10.1002/ep.12745

Luo, X., \& Deng, F. (2019). Nanomaterials for the Removal of Pollutants and Resource Reutilization. London: Elsevier.

Mahanta, V., Raja, M., \& Kothandaraman, R. (2019). Activated Carbon from Sugarcane Bagasse as a Potential Positive Electrode Catalyst for Vanadium Redox Flow Battery. Materials Letters, 247, 63-66. https://doi.org/10.1016/j.matlet.2019.03.045

Malik, P. K. (2003). Use of Activated Carbons Prepared from Sawdust and Rice Husk for Adsorption of Acid Dyes: A Case Study of Acid Yellow 36. Dyes and Pigments, 56, 239-249. https://doi.org/10.1016/S0143-7208(02)00159-6

Marcelo, B. M. (2011). Solvent Extraction for Metal and Water Recovery from Industrial Wastes and Effluents. Revista Escola de Minas, 64, 51-55. https://doi.org/10.1590/S0370-44672011000100006

Mashael, A., Ghadah, A., \& Rasmiah, A. (2013). Removal of Crystal Violet Dye from Aqueous Solutions onto Date Palm Fiber by Adsorption Technique. Journal of Chemistry, 2013, Article ID: 210239. https://doi.org/10.1155/2013/210239

Menaka, S., \& Rana, S. (2017). Decolourization Studies of a Novel Textile Dye Degrading Bacterium. In F. Kurisu, A. Ramanathan, A. Kazmi, \& A. Kumar (Eds.), Trends in Asian Water Environment Science and Technology (pp. 63-69). Chem: Springer. https://doi.org/10.1007/978-3-319-39259-2_5

Nasiru, A., \& Magaji, B. (2016). Adsorption of Alizarin and Fluorescein Dyes onto Palm Seeds Activated Carbon: Kinetic and Thermodynamic Studies. Journal of the Chemical Society of Pakistan, 38, 604-613.

Nevine, K. A. (2008). Removal of Reactive Dye from Aqueous Solutions by Adsorption onto Activated Carbons Prepared from Sugarcane Bagasse Pith. Desalination, 223, 152-161. https://doi.org/10.1016/j.desal.2007.01.203

Palanivel, S., Mani, A., \& Thayumanavan, P. (2012). Utilization of Agro-Industrial Waste Jatropha curcas Pods as an Activated Carbon for the Adsorption of Reactive Dye Remazol Brilliant Blue R (RBBR). Journal of Cleaner Production, 22, 67-75. https://doi.org/10.1016/j.jclepro.2011.09.017

Qadir, I., \& Chhipa, R. (2017). Synthesis, Characterization and Evaluation of Adsorption Properties of Activated Carbon Obtained from Neem Leaves (Azadirachta indica). Oriental Journal of Chemistry, 33, 2095-2102. https://doi.org/10.13005/ojc/330460

Rackley, S. A. (2017). Carbon Capture and Storage (2nd ed.). London: Elsevier. https://doi.org/10.1016/B978-0-12-812041-5.00002-7

Rai, P., Banerjee, S., \& Jayaram, R. (2007). Removal of Disperse Dyes from Aqueous Solution Using Sawdust and BDTDA-Sawdust. Journal of Dispersion Science and Technology, 28, 1066-1071. https://doi.org/10.1080/01932690701524752

Ramazan, A., Tolga, D., Musa, S., Ali, R., \& Yunus, O. (2016). Adsorption of Crystal Violet on Activated Carbon Prepared from Coal Flotation Concentrate. IOP Conference Series: Earth and Environmental Science, 44, Article ID: 052022. https://doi.org/10.1088/1755-1315/44/5/052022

Sarita, D., Khan, T., \& Imran, A. (2012). Removal of Direct Red 81 Dye from Aqueous Solution by Native and Citric Acid Modified Bamboo Sawdust-Kinetic Study and Equilibrium Isotherm Analyses. Gazi University Journal of Science, 25, 59-87.

Sathian, S., Rajasimman, M., \& Karthikeyan, C. (2013). Biodegradation and Decolorization of Textile Dye Wastewater Using Ganoderma lucidum. 3 Biotech, 3, 71-79. https://doi.org/10.1007/s13205-012-0073-5 
Tais, L., Ronix, A., Osvaldo, P., Lucas, S., \& Paatricia, K. (2016). Mesoporous Activated Carbon from Industrial Laundry Sewage Sludge: Adsorption Studies of Reactive Dye Remazol Brilliant Blue R. Chemical Engineering Journal, 303, 467-476. https://doi.org/10.1016/j.cej.2016.06.009

Taner, E., \& Fatma, O. (2016). Characterization of the Adsorption of Disperse Yellow 211 on Activated Carbon from Cherry Stones Following Microwave Assisted Phosphoric Acid Treatment. Journal of Analytical Letters, 49, 917-928. https://doi.org/10.1080/00032719.2015.1086776

Tanweer, A., Mohammad, D., Arniza, G., Rafatullah, M., Ibrahim, M., Hashim, R., \& Othman, S. (2012). The Use of Date Palm as a Potential Adsorbent form Wastewater Treatment: A Review. Environmental Science and Pollution Research, 19, 1464-1484. https://doi.org/10.1007/s11356-011-0709-8

Tijen, E. B., \& Filiz, E. (2019). Batch and Column Studies for Removal of Sulphate from Real Wastewater Using Ion Exchange Resin. Sakarya University Journal of Science, 23, 810-816. https://doi.org/10.16984/saufenbilder.538174

Wang, L. (2013). Removal of Disperse Red Dye by Bamboo Based Activated Carbon: Optimization, Kinetics and Equilibrium. Environmental Science and Pollution Research, 20, 4635-4646. https://doi.org/10.1007/s11356-012-1421-z

Yavuz, O., \& Aydin, A. (2006). Removal of Direct Dyes from Aqueous Solution Using Various Adsorbents. Polish Journal of Environmental Studies, 15, 155-161.

Yu, Q., Ning, P., Li, M., \& Tang, X. (2019). Characterization of Metal Oxide Modified Walnut Shell Activated Carbon and Its Application for Phosphine Adsorption: Equilibrium, Regeneration and Mechanism Studies. Journal of Wuhan University of Technology, Materials Science Edition, 34, 487-495. https://doi.org/10.1007/s11595-019-2078-y

Zhen, W., Tan, Y., Yang, Y., Zhao, X., Liu, Y., Niu, L., Brandon, T., \& Kong, L. (2018). Pomelo Peels Derived Porous Activated Carbon Micro Sheets Dual Doped with Nitrogen and Phosphorus for High Performance Electrochemical Capacitors. Journal of Power Sources, 378, 499-510. https://doi.org/10.1016/j.jpowsour.2017.12.076 